\title{
SPIRITUAL DEVELOPMENT OF MAN IN THE CONTEXT OF CHRISTIAN-ANTHROPOLOGICAL VIEWS IN PHILOSOPHICAL THOUGHT OF KIEVAN RUS
}

\section{Hudzenko O.}

\section{INTRODUCTION}

The christening of Rus in 988 marked the beginning of changes in the public consciousness and the foundations of ideological life in Kievan Rus (Saranchin, Kuskova, 2010: 135). There is a formation not only of the social system of society, but also the worldview of ancient man. Therefore, the ancient scribes turn to the spiritual development of the individual.

A number of scholars consider the religious and philosophical searches of Kyiv sages from different positions. In particular, L. Andrusiv explores rationalist tendencies in Ukrainian philosophical thought XI - beg. XVII century (Andrusiv L., 2017), T. Tselyk - the problem of man in the philosophical culture of Kievan Rus (Tselik T., 2003), L. Yakovets monasteries and cathedrals of Ukraine as a personification of Christian written culture (Yakovets L., 2009), I. Maidanyuk clarifies the peculiarities of the problem of freedom in the philosophical culture of Ukraine IX - XVIII centuries (Maidaniuk I., 2003), Yu. Zavgorodniy reveals the essential characteristics of the idea of a sacred center in the culture of Kievan Rus (Zavhorodnii $Y u$., 2002), I. Zherebylo addresses the problem of the meaning of human life in Ukrainian philosophy (Zherebylo I., 2002).

It should be noted that during the formation of the culture of Kievan Rus', which is characterized by the formation of national values on the basis of universal Christian ideals, there is a creation of "archetype", a standard of spiritual life for all future generations. Therefore, the problem remains relevant, as it relates to the direction of historical and philosophical research to identify the peculiarities of the formation of national spiritual values. The specificity of such research always implies the presence of an element of novelty. In particular, consider the influence of Christianity on the anthropological ideas of Kievan Rus.

The purpose of the study, from which its tasks follow, is to analyze the influence of Christianity on the importance of life problems of human existence, in particular - on the anthropological ideas of Kievan Rus.

The scientific novelty of the study is that it focuses on Christian anthropological points of view, represented by Ukrainian medieval 
philosophical and religious thought and reinterpreted by the wise men of Kievan Rus. Our research is based on religious methods of studying historical and philosophical problems. We also used such methods as textual, systematization, comparative-historical. We were guided by the principles of historicism and objectivity.

\section{Christianity as a factor of spiritual culture formation of Kievan Rus'}

The historical period we are studying is the one in which the tradition of Ukrainian philosophical thought is formed. It is she, starting from the XI century, further determines the specifics of the philosophical thinking of the Ukrainian people. It will be recalled that its origins are the ideas of ancient Greek thinkers, reinterpreted by Byzantine Christian philosophy, as well as the legacy of the philosophical direction of national culture, which preserved the mythological ideas of the Eastern Slavs. In a situation of duality of faith christianity is built above paganism.

It should be noted that the introduction of Christianity made it possible to join the achievements of world culture. Intensive contacts with Byzantium, Bulgaria made it possible to use as a source of development of philosophical thought the achievements of ancient and Byzantine philosophy that prevailed at the time. As V. Horsky aptly points out, Christianity serves as a kind of catalyst for the process that accompanied the assimilation of the world's ideological heritage in the culture of Kievan Rus (Horskyi, 1993).

It is noteworthy that Eastern patristic works by Ivan Damaskin, Dionysius the Areopagite, and later Gregory of Sinai and Gregory Palamas were the first theoretical sources on which Ukrainian thinkers made their philosophical generalizations, their conclusions about God, the universe and man. Among the Christian writers of the East, the Hellenic trend, founded by Origen and Gregory of Nyssa, persisted for a long time. He assisted the concordance of Christian faith with Greek philosophical sciences.

Due to the specific features of Christianity as a "religion of limning" with its inherent respect for the Word, the culture that develops under the auspices of this religion acquires a book character. This encourages understanding of the meaning of "hidden" in the word, stimulates the search for its symbolic meaning, reflection on it. Slowly there are processes of restructuring of social consciousness, associated with its adaptation to the philosophical system. Philosophizing begins with attempts to reveal the meaning hidden in the word, to "liberate" the Word from everyday meaning for the development of symbolic, metaphorical thinking. In book culture, the word is understood as an external expression of thought. This begins the path of philosophy. 
Ancient Rus scribes became acquainted with the philosophy of Christian Orthodoxy and antiquity through translations of selected texts of the Old and New Testaments, the works of Basil the Great of Caesarea, Gregory the Theologian of Constantinople, Gregory of Nyssa, John of Damascus and other Eastern authors, as well as from translations of the works of Pythagoras, Aristotle, Epicurus, Democritus, Plato and other ancient thinkers.

The existence in Rus of rich in content philosophizing is evidenced by the analysis of the texts "Word of Law and Grace" by Metropolitan Hilarion, "Collection of 1073", "Collection of 1076", Translations from the book of Genesis, excerpts entitled "Six Days", "Chronicle" John Malala and George Amartol, works by Metropolitans Nikifor and Kliment Smolyatych, Bishop Kirill Turovsky, a collection of texts "The Bee" and other sources (Kaverina, 2010:15).

Christian doctrine consists of metaphysics as a doctrine of the transcendent essence of being, of the world and the meaning of being, and of ethics as a doctrine of the relation of man to man. The ratio of these components is determined by the predominant role of ethics, which leaves a decisive imprint on the nature of teaching as a whole. Medieval philosophical thought can be described as a kind of moral-philosophical-theological syncretism. Ancient Kievan Rus' culture develops mainly in the direction not of theoretical knowledge, but of spiritual and practical assimilation of the world (Horskyi, Krymskij, 1985).

Thus, at the time of the birth of philosophical thinking in the culture of Kievan Rus, world philosophy had more than a thousand years of history. Christianity has become a powerful impetus for the creation of incentives that would contribute to intensive intellectual work on understanding complex theoretical material.

The result of the interaction of Christian and popular worldviews is a variety of approaches to solving philosophically significant problems. This is clearly demonstrated on the monuments of ancient writing. Each of the available approaches to varying degrees reflected elements of culture that interacted with Christianity in the spirituality of Kievan Rus. This, in turn, led to a pluralism of worldviews, which together formed a picture of the spiritual life of Kievan Rus. For this reason, the philosophical thought of Kievan Rus acquires a polyphonic sound due to the intersection of cultures that coexisted and interacted in the ancient spiritual life.

The influence of the people's worldview on the understanding of Christian religious dogmas was especially evident in the fact that in Rus, along with the cult of local saints, which was formed on the basis of tribal idolatry, the cult 
of the Virgin becomes paramount. It is based on Slavic ideas about the ancestor of the Slavic family - Rozhanitsa. The transition of a religious cult from the cult of Christ to the cult of the Virgin had fundamental consequences in the development of ancient Rus spiritual ideals. Because the Mother of God, unlike Christ, who was the "savior" of the human soul only, "saves" the whole world and thus makes "bodily existence" an accomplice of holiness and heavenly bliss. Nature, in general, the world ceases to be a source of sin.

Thus, given the spiritual-objective component, the philosophical thought of pre-Mongol Rus is an adequate reflection of the Greco-Slavic, Christian type of culture with its inherent emphasis on the problem of "man-God", through the prism of understanding the limits of human existence. Philosophical ideas that gravitate to ancient, East Slavic mythological ideas interact with the dominant culture. The culture of Kievan Rus during the period of the establishment of the Christian worldview is characterized by a contradictory combination of pagan and Christian traditions.

\section{The role of Christianity in the formation moral and ethical views of the wisemen}

A feature of the period of Christianization was the worldview and cultural dualism. "Duality of faith" manifested itself in a mixture of pagan ideas of the Slavs and the foundations of the Christian worldview. For example, tribal idolatry was the basis for the veneration of Christian saints, and the veneration of the Mother of God is based on notions of the female origin. Both the earthly and the heavenly world were perceived through the prism of practical morality, derived from Christian doctrine.

The basis of the moral and ethical considerations of the wisemen is the question of the origin of good and evil, which is not cosmological but moral in nature and is related to the will of man. The key categories of ancient ethical thought include: "grace", "fate", "love", "good". The translations of John Chrysostom, who focused on the ethical and religious content of the Gospel and taught the charitable love of agape in its social aspect (protecting the poor and exposing the rich), were very popular among the ancient Rus educated population. Also known were the poetic works of Ephraim Sirin, filled with biblical lyrics and repentance.

Under the influence of pagan ethics, the ancient Rus man has a different understanding of Christian charity itself: it recognizes as charitable not the one who spends time in prayer, but the one who is charitable in life. The "Word about Ordeals", a monument of the twelfth century, refers to the sinful moral crimes: lies, slander, envy, anger, pride, violence, theft, fornication, greed. 
Among Christian virtues, love of neighbor is paramount. The purpose of man on earth is to actively serve people and do them good. The activity of empathy was seen as the imitation of a person's higher moral standards. It is worth seeing the desire to become like Christ in terms of individual earthly existence.

Each stratum of society had its own list of necessary qualities, and common to all was the understanding of "real" life as a moral activity. He foresaw the maximum possible realization of life goals, which is seen as service to others. In particular, Vladimir and Yaroslav can be an example of the prince's "service". In Hilarion's "Word of Law and Grace", the first Christian princes of Kyiv were courageous defenders of their native land, mentors of their people, and guardians of the Orthodox faith. It is noteworthy that they not only teach others a charitable life, but also live according to the requirements of truth and faith (Lhtopis, 1903).

Thus, the ethical platform of Christianity was a fundamentally new doctrine. Christian dialectics has managed to transfer the ethical problem from the sphere of external relations to the sphere of internal self. Until now, morality was seen as a factor designed to regulate relations between different people, overcoming their will in the name of social needs and interests. Man as a subject of ethical principles was considered in relations with others. Now the problem is concentrated inside the person. Everyone's relationship with himself came to the fore, overcoming internal arbitrariness.

\section{The influence of Christian values on the understanding of the essence of man in the philosophical thought of Kievan Rus'}

As a result of the interaction of various ideas in the Kievan Rus', a religious culture was formed, which reflected the diversity of forms of medieval religious life. It is noteworthy that Christianity was perceived in Rus in its eastern, Byzantine version. This circumstance significantly affected the features of ancient anthropology. As noted by T. Chumakova, the core of the image of man, which gradually developed in ancient culture, was the idea of the high purpose of man, created in the "image and likeness of God". This image reflected a higher reality, which was extremely significant in medieval notions (Chumakova, 2002:15).

In ancient Rus, the Christian religion was strongly associated with literature. In general, ancient culture is a hypertext, the core of which is the Christian faith. According to T. Chumakova, most of the texts were based on a religious element, the main function of which was to develop in the minds of the addressee means of expression of Christian spirituality. This feature was the reason that literature contributed to the formation of those ideas about man 
that already existed in the framework of Eastern Christian anthropology. Therefore, his main theme was salvation, which was understood as the purpose of philosophical practice and life. A characteristic feature of the preMongol period of ancient culture was the desire of scribes, icon painters, architects in their work to combine both life plans: earthly and heavenly (Chumakova, 2001: 137).

Anthropological ideas of ancient thinkers were formed under the influence of Byzantine patristic literature, Bulgarian philosophical and theological texts and pagan views with elements of mythological consciousness. In particular, such a synthesis is traced in the Kievan Rus' ideas about the first man. For example, the "Conversation of the Three Saints" speaks of the eight parts from which Adam was created: "1) the body was taken from the earth, 2) the bones from the stone, 3) the blood from the Red Sea, 4) the eyes from the sun, 5) from the clouds - thoughts, 6) from the breath - hair, 7) from the light - the soul, 8) the God himself breathed his soul and gave power over all visible and invisible in the waters and mountains, on earth and in heaven" (Apokrify, 1980: 142). In "Svyatoslav's Collection of 1073" in the work entitled "Justin the Philosopher on the True Faith" it is said that the human body, like the whole world, consists of fire, air, water, earth (Gromov, Milkov, 2001: 64).

The concept of the human soul is associated with both paganism and Christianity. In particular, in the "Collection of Svyatoslav in 1073" the terms "body" and "flesh" are contrasted with "spirit" and "soul", respectively. The spirit is independent of the body, which is formed by the flesh and soul. The soul is a part of the body, but opposite to the flesh. All the shortcomings of man are inseparable from the flesh. Evil is related to the fall as a result of "depravity of flesh" (Izbornyk 1073, 2015: 63).

In the "Collection of 1076" the author, according to the canon, presents two natures in Christ: the Divine and the human. Thus, the soul and the body are considered as one whole and inseparable, differing only in purpose, functions and qualities (Izbornyk 1076, 2015: 70).

"Collection of 1076" depicts seven stages, the passage of which brings man closer to God: 1) man is immersed in carnal passions and stands before God as "before death"; 2) a person accountable to God as a debtor; 3) man as a slave with fear and prayer; 4) a person is like a mercenary who has the will and wants to receive a salary; 5) a person who stands before God as before a friend and addresses him; 6) a person boldly addresses God in a filial way; 7) man "merges" with God (Izbornyk 1076, 2015: 69). This model of "ascent" to God demonstrates the existence of mythological remnants in the Christian understanding of the relationship with heaven: a person in another 
world is thought of as a participant in the social relations of "this" world (debtor, mercenary) (Saranchin, Kuskova, 2010: 138).

Regarding the views of Metropolitan Nicephorus (XI - early XII century) on the relationship of divine and earthly, soul and flesh, it should be noted: he considers the two-way interaction of soul and body in contrast to the traditional church view of them both individually and in confrontation. The soul has precedence over the flesh and can control it through fasting, which opens the spirit to power over the body. The bodily principle is endowed with sinful qualities, and the rational and the spiritual are inherently divine and disembodied. Thus, in the philosophical thought of Metropolitan Nicephorus there are clear platonic influences (Semikopova, 2009: 230).

Nicephorus' epistemological views were as follows: man knows the material world through the senses, knowledge of God or at least approach to Him is possible through a rational beginning of the soul (theological rationalism) and "desirable" (mystical "eroticism" of the Byzantine ascetic tradition). But the primacy in the matter of cognition belongs to the mind as the highest part of the soul. Nicephorus tends to rationalize the knowledge of God, which is inherent in the platonic tradition.

Thus, the anthropological ideas of Metropolitan Nicephorus from a philosophical point of view can be described as Christian Platonism: a Christian in his worldview, a supporter of the mystical and ascetic tradition of Eastern Christianity with his inherent views on Divine Eros, knowledge of God, the mysticism of light, Metropolitan Nicephorus is inclined to both the platonic concept of the soul and platonic epistemology.

Cyril Turovsky in allegorical form reflects on the relationship of heavenly and earthly, spiritual and corporeal. Cyril sees salvation in monasticism, in flight from the world, condemning sensuality. In his teachings, the body is a "city" and the senses are its population. Soul and body are interdependent and equally prone to sin. In their ontological qualities, they are not the image and likeness of God, because the image of God reflects the dominant position of man in relation to the world. As for God, man is a being who is not destined to cross the ontological abyss. Man creates himself as a temple for the Deity, but not man ascends to God, and God always ascends to her. The consequence of this is only the cataphatic knowledge of God through creation and revelation.

Thus, Cyril Turovsky adheres to the principles of biblical anthropological integrity of the mental and physical nature of man, which is transcendent to God. In particular, according to O. Vdovina, "The Parable of the Blind and Lame" can be considered a vivid example of Kirill Turovsky's unusual understanding of the problem of human sinfulness in the ethical and 
anthropological plane, which is manifested in the relationship between soul and body, in which the soul plays a leading role.

Man's sinfulness consists in his failure to fulfill his purpose. Accordingly, a person's vocation is self-development, which is impossible without respect for one's soul. Ancient Rus wise men emphasize the integrity of the human person, which is manifested in the unity of soul and body both during life and after death (Vdovyna, 2002: 45).

From the interpretation of the essence of the image and likeness of God in man by Cyril Turovsky follows his statement of the transcendence of God and the world, which is leading in his teaching. Man is the image of God, but he has no physical or spiritual resemblance to God. In this idea there is a discrepancy with the leading position of the Eastern Christian tradition, which sees an ontological characteristic in the image of God, the possibility of man's advancement to God, assimilation to God and deification. Cyril believes that even the spiritual qualities of human nature do not liken man to God.

In the question of the knowledge of God, Cyril takes a cataphatic position and also prefers the irrationalist position, although he notes examples of sacred history, where the knowledge of God occurred through sensory experience. From his point of view, such a sensual knowledge of God is a consequence of God's revelation to the world, and the culmination of this revelation is the incarnation of God in Christ (Alekseeva, 2007: 81), (Semikopova, 2011: 22).

Thus, it should be noted that in the works of the Kievan Rus period there were widespread reflections on the practice of controlling the body and soul through contemplative life, the humiliation of the senses, prayer. Because it was important for the ancient Rus scribe to describe a certain ideal so that the reader could achieve it in practice.

\section{CONCLUSIONS}

Analyzing the influence of Christianity on the anthropological ideas of the Kievan Rus, we conclude that the ancient wise men paid much attention to reflection on the explanation of existence, knowledge and man. This was facilitated by literature, forming such ideas about man, which already existed in the framework of Eastern Christian anthropology.

At the time of the birth of philosophical thinking in the culture of Kievan Rus, world philosophy had more than a thousand years of history. Christianity was a powerful impetus for the creation of incentives that would contribute to the intense intellectual work on the understanding of complex theoretical material. It not only contributed to the translation on domestic soil of the 
achievements of world philosophical thought, but also acted as a catalyst that accompanied the process of understanding and assimilation of this information.

Thus, the Christianization of Kievan Rus was a kind of the impetus for the development of ancient philosophical thought. The texts of the Kyivan scribes show a huge influence of the previous cultural and ideological tradition (mythological ideas of Slavic paganism), as well as the Christian line, which came to Rus through Byzantine and Bulgarian philosophical literature.

Given the spiritual and substantive component, the philosophical thought of pre-Mongol Rus is an adequate reflection of the Greco-Slavic, Christian type of culture with its inherent emphasis on the problem of "man-God", through the prism of which the comprehension of the ultimate foundations of human existence is carried out. Philosophical ideas, which tend to ancient, East Slavic mythological ideas, interact with the dominant culture.

In our opinion, historical and philosophical research on the proposed topic allows not only to trace the peculiarities of the vision of any meaningful life issues of human existence, but also to outline a number of problems relating, in particular, moral and ethical principles of human existence in general.

\section{SUMMARY}

In the article the author analyzes the influence of Christianity on the meaning of life problems of human existence, in particular - on the anthropological ideas of Kievan Rus. It is noted that the introduction of Christianity has allowed us to join the world's cultural achievements. The main features of anthropological thought of Kievan Rus are considered and the influence of Christianity on the meaning of human existence is analyzed. It is noted that Christianization contributed to the development of ancient philosophical thought. Not surprisingly, the text of Kyiv scribes traces the great influence of previous cultural and ideological traditions (mythology of Slavic paganism) and the Christian way, which was introduced in Rus through Byzantium and Bulgarian philosophical literature. One of the characteristics of the period of Christianization is the dualism of worldview and culture. In the philosophical study of the ancient Rus sages, first of all, there was a comprehension of the explanation of being, cognition and man. It is emphasized that the literature contributed to the formation of those ideas about man that already existed in the framework of Eastern Christian anthropology. The author notes that medieval philosophical thought can be described as the unity of moral philosophy and theology, which is inherent in the culture of Kievan Rus. Thus, the development of ancient culture was 
mainly not in the direction of theoretical knowledge, but in the direction of mastering the spiritual and life practice.

\section{REFERENCES}

1. Alekseeva T. (2007). Obraz cheloveka v kulture Srednih vekov [The image of a person in the culture of the Middle Ages]. XII Nizhegorodskaya sessiya molodyh uchenyh. Nizhny Novgorod. S. 82-83. [in Russian]

2. Andrusiv L. (2017). Doslidzhennia ratsionalistychnykh tendentsii v ukrainskii filosofskii dumtsi XI-XVII st.: ohliad istoryko-filosofskykh prats [Research of rationalist tendencies in the Ukrainian philosophical thought of XI-XVII centuries: the review of historical and philosophical works]. Hileia: naukovyi visnyk. Vyp. 121. S. 62-66. [in Ukrainian]

3. Apokrify. Beseda treh svyatitelej. Pamyatniki literatury Drevnej Rusi. XII vek [Apocrypha. Conversation of three saints. Literary monuments of Ancient Rus'. XII century]. Dmitriev L., Lihachev D. (1980). Moscow: Hudozh. lit. S.137-147. [in Russian]

4. Vdovyna O. (2002). Osmyslennia Kyrylom Turovskym problemy hrikhovnosti liudyny u Prytchi pro sliptsia ta khromtsia [Cyril Turovsky's understanding of the problem of human sinfulness in the Parable of the Blind and Lame]. Naukovi zapysky NaUKMA. Seriia filosofiia ta relihiieznavstvo. Yuvileinyi vypusk do 70-richchia vid dnia narodzhennia Vilena Serhiiovycha Horskoho. Kyiv: Vydavnychyi dim "KM Academia". T. 20. S. $44-46$. [in Ukrainian]

5. Gorskij V., Krymskij S. (1985). Filosofskie idei v otechestvennoj srednevekovoj kulture [Philosophical Ideas in Rus Medieval Culture]. Filosofskie nauki. № 5. S. 91-99. [in Russian]

6. Horskyi V. (1993). Narysy z istorii filosofskoi kultury Kyivskoi Rusi (ser. KhII-ser.KhIII st.) [Essays on the history of the philosophical culture of Kievan Rus (mid-XII-mid-XIII century)]. Kyiv: Naukova dumka. 164 s. [in Ukrainian]

7. Gromov M., Milkov V. (2001). Idejnye techeniya drevnerusskoj mysli [Currents of ideas in ancient Rus thought]. St. Petersburg: Izd-vo Russkogo Hristianskogo gumanitarnogo instituta. 959 s. [in Russian]

8. Zherebylo I. (2002). Problema sensu zhyttia liudyny v ukrainskii filosofii XI - pershoi polovyny XVII st. [The problem of the meaning of human life in the Ukrainian philosophy of the XI - first half of the XVII century]: avtoref. dys. na zdob. nauk. stup. kand. filoc. nauk: 09.00.05. Lviv: Lvivskyi nats. un-t im. I. Franka. 18 s. [in Ukrainian] 
9. Zavhorodnii Yu. (2002). Ideia sakralnoho tsentru v kulturi Kyivskoi Rusi: KhI st. - persha tretyna XIII st. (do kharakterystyky prostorovochasovykh uiavlen) [The idea of a sacred center in the culture of Kievan Rus: XI century. - the first third of the thirteenth century (to the characteristics of space-time representations)]: avtoref. dys. kand. filosof. nauk: 09.00.05. Kyiv: Kyiv. nats. un-t im. T.Shevchenka. 20 s. [in Ukrainian]

10. Izbornyk Sviatoslava 1073 roku. Khrestomatiia z istorii ukrainskoi movy X-XIII st. [Collection of Svyatoslav 1073 Textbook on the history of the Ukrainian language X-XIII centuries]. V.Nimchuk. (2015). KyivZhytomyr. S. 59-67. [in Ukrainian]

11. Izbornyk Sviatoslava 1076 roku. Khrestomatiia z istorii ukrainskoi movy X-XIII st. [Collection of Svyatoslav in 1076. Textbook on the history of the Ukrainian language of the X-XIII centuries]. V.Nimchuk. (2015). KyivZhytomyr. S.68-72. [in Ukrainian]

12. Kaverina E. (2010). Religiozno-filosofskie iskaniya na Rusi v $\mathrm{X}$ - nachale XIII vekov [Religious and philosophical searches in Rus X - early XIII centuries]: avtoref. dis. kand. filos. nauk: 09.00.03. Voen. un-t MO. Moscow. 23 s. [in Russian]

13. Lhtopis Nestora so vklyucheniem poucheniya Vladimira Monomaha [Chronicle of Nestor with the inclusion of the teachings of Vladimir Monomakh]. (1903). St. Petersburg: Tip.Glazunova. 202 s. [in Russian]

14. Maidaniuk I. (2003). Problema voli u filosofskii kulturi Ukrainy IX - XVIII st. [The problem of freedom in the philosophical culture of Ukraine IX - XVIII centuries]: avtoref. dys. kand. filosof. nauk: 09.00.05. Lviv: Lviv. nats. un-t im. I.Franka. 19 c. [in Ukrainian]

15. Saranchin Yu., Kuskova O. (2010). Dvojstvennost drevnerusskoj antropologii [The duality of ancient Rus anthropology]. Izvestiya Uralskogo gosudarstvennogo ekonomicheskogo universiteta. Vyp. 6 (32). S. 135-139. [in Russian]

16. Semikopova T. (2009). Platonizm i hristianstvo v antropologicheskih predstavleniyah Kievskogo mitropolita Nikifora (XII vek) [Platonism and Christianity in the anthropological concepts of the Kyiv Metropolitan Nicephorus (XII century)]. XIII Nizhegorodskaya sessiya molodyh uchenyh. Nizhny Novgorod. S. 230-231. [in Russian]

17. Semikopova T. (2011). Filosofsko-antropologicheskie predstavleniya $\mathrm{v}$ russkoj duhovnoj kulture XII veka: ot teorii k praktike [Philosophical and anthropological concepts in Rus spiritual culture of the XII century: from theory to practice]: avtoref. dis. kand. filos. nauk: 09.00.13. Nizhegorod. gosud. pedag. univ. Nizhny Novgorod. 27 s. [in Russian] 
18. Tselik T. (2003). Problema liudyny u filosofskii kulturi Kyivskoi Rusi [The problem of man in the philosophical culture of Kievan Rus]: avtoref. dys. kand. filos. nauk: 09.00.05. Kyiv: In-t filosofii im. H.S.Skovorody NAN Ukrainy. 21 s. [in Ukrainian]

19. Chumakova T. (2001). "V chelovecheskom zhitelstve mnozi obrazy zryatsya". Obraz cheloveka v kulture Drevnej Rusi ["In human life, many images are seen". The image of a person in the culture of Ancient Rus]. St. Petersburg: Sankt-Peterburgskoe filosofskoe obshestvo. 242 s. [in Russian]

20. Chumakova T. (2002). Obraz cheloveka v kulture Drevnej Rusi (opyt filosofsko-antropologicheskogo analiza) [The image of a person in the culture of Ancient Rus (the experience of philosophical and anthropological analysis)]: avtoreferat dis. d-ra filosofskih nauk: 09.00.13. St. Petersburg. 39 s. [in Russian]

21. Yakovets L. (2009). Monastyri ta sobory Ukrainy yak uosoblennia khrystyianskoi pysmennoi kultury [Monasteries and cathedrals of Ukraine as a personification of Christian written culture]: avtoref. dys. kand. filosof. nauk: 09.00.11. Kyiv: Kyiv. nats. un-t im. T.Shevchenka. 19 c. [in Ukrainian]

\section{Information about the author: Hudzenko O.,}

Candidate of Philosophical Sciences, Associate Professor, Associate Professor at the Department of World History and Philosophy, Lesya Ukrainka Volyn National University 13 Voli ave., Lutsk, Volyn region, 43025, Ukraine 